\title{
How Many Beds?
}

\section{A survey of needs for treatment and care in an in-patient unit}

Frank Holloway, Consultant Psychiatrist, Gaius Davies, Consultant Psychiatrist, Marisa Silverman, Consultant Psychiatrist and Tony Wainwright, Principal Clinical Psychologist, Department of Psychological Medicine, King's

College Hospital, London SE5

Over the past 20 years the Department of Psychological Medicine at King's College Hospital has gradually taken responsibility for the provision of psychiatric services to the East Lambeth sector of the Camberwell Health District. A small District General Hospital (DGH) in-patient unit was opened in 1972, and since then it has been the aim of the Department to provide a comprehensive locally based psychiatric service. Slow progress has been made compared with the developments that have taken place in the South Southwark sector of the District, which have been fostered by the Maudsley Hospital. ${ }^{1}$ With the impending closure of Cane Hill Hospital, on which the District has historically relied, the object of a completely local service is rapidly becoming a reality. Releasing the resources hitherto tied to the large institution presents an unparallelled opportunity for change.

The local services have been subject to severe criticism particularly for being too bed-oriented and insufficiently aware of the needs of the local community. ${ }^{2}$ However, severe resource constraints face the Mental Health Care Group (as it has now become) with a crucial dilemma. If developments are to occur these will have to come from within the existing budget. How is the balance to be struck between in-patient beds, by far the most expensive part of the service, and other types of provision?

A census carried out in 1986 identified 86 East Lambeth residents occupying acute psychiatric in-patient beds (105/100,000 total population), of whom a quarter were cared for in the adjacent Maudsley Hospital. The most recent DHSS 'guidelines' ${ }^{3}$ suggest that between 30 and 50 acute beds per 100,000 population will be required, a figure that includes provision for the assessment of dementia. The East Lambeth service includes a day hospital with an average daily attendance of 55 (68/100,000 population), although it caters largely for the chronically mentally ill rather than 'acute' patients, together with a small community psychiatric nursing (CPN) service and the usual range of out-patient facilities. In keeping with its tradition, much attention has been paid by the Department to the needs of patients within the General Hospital, ${ }^{4}$ and to activities of teaching and research. Clearly the pattern of services within the area differs considerably from that envisaged by the DHSS.

The routinely available data on the use of psychiatric services by residents of the East Lambeth sector are minimal, consisting only of the very delayed and worryingly inaccurate returns on admission data to the DGH wards which are collected by Hospital Activity Analysis clerks. We wished to identify in more detail the characteristics of the patients who used the East Lambeth in-patient services and to explore the possibility that some shift in resources to alternative styles of provision would be appropriate.

The survey

A survey of the in-patient wards within the East Lambeth service, including the Camberwell wards in Cane Hill Hospital, was carried out. A survey schedule and guide notes were prepared. Each of the wards was visited on the census day and a schedule completed on each patient in conjunction with members of the multi-disciplinary team caring for the patient. Basic sociodemographic data were collected. The hospital diagnosis was noted and ratings made of the patient's psychiatric, physical and social problems. The team then made judgements about each patient's needs for residential and day care and 'personal support services.' The ready availability was assumed of a comprehensive range of provision, including staffed housing, a variety of day settings and a multi-disciplinary home treatment team capable of offering 24 hour support to patients in their own homes. ${ }^{5}$

All wards were surveyed, including a small liaison psychiatry ward in the teaching hospital (occupied exclusively by patients from outside the catchment area), the dementia service (within which there was no separate assessment facility) and long-stay wards in the mental hospital. We report the results of the survey of the acute wards.

\section{The findings}

There were 71 in-patients on the acute unit at the time of the survey, an occupancy level of $88 \%$. Forty of the patients were women $(56 \%)$. Sociodemographic characteristics of the patients are shown in Table I. Diagnosis and length of stay are shown in Table II. It can be seen that the unit was offering predominantly a psychosis service. A significant proportion of the patients were long-stay.

Of the patients, $28 \%$ were detained under the Mental Health Act. The proportion of patients from ethnic minorities $(28 \%)$ closely reflected the proportion in the local community (24\%). Afro-Caribbean and Asian patients were no more likely to be detained under the Mental Health Act than white patients. 
TABLE I

Characteristics of patients

\begin{tabular}{|c|c|c|}
\hline & $n$ & $(\%)$ \\
\hline \multicolumn{3}{|l|}{ Age } \\
\hline$<65$ yrs & 53 & (75) \\
\hline$>65 \mathrm{yrs}$ & 18 & (25) \\
\hline \multicolumn{3}{|l|}{ Marital status } \\
\hline Married/cohabiting & 18 & (25) \\
\hline Single & 31 & (44) \\
\hline Separated/divorced & 12 & (17) \\
\hline Widowed & 10 & (14) \\
\hline \multicolumn{3}{|l|}{ Ethnicity } \\
\hline 'Black' & 20 & (28) \\
\hline 'White' & 51 & (72) \\
\hline
\end{tabular}

TABLE II

Diagnosis and length of stay.

\begin{tabular}{lrr}
\hline \multicolumn{1}{c}{ Case note diagnosis } & $n$ & $(\%)$ \\
\hline Schizophrenia & 27 & $(38)$ \\
Manic depressive psychosis & 23 & $(32)$ \\
Neurotic depression & 7 & $(10)$ \\
Other neurosis & 1 & $(1)$ \\
Personality disorder & 4 & $(6)$ \\
Drug/alcohol abuse & 2 & $(3)$ \\
Organic psychosis & 5 & $(7)$ \\
Not diagnosed & 2 & $(3)$ \\
& & \\
\hline Length of stay & & \\
$\quad<1$ month & & \\
$1-5$ months & 20 & $(28)$ \\
$6-11$ months & 32 & $(45)$ \\
$12+$ months & 11 & $(11)$ \\
\end{tabular}

Team judgements of the patients' needs for residential care are shown in Table III. Given a full range of alternative facilities only 29 patients $(41 \%)$ were rated as requiring care in a hospital setting. Thirteen patients $(18 \%)$ were rated as dischargeable home, either to family or alone, if appropriate support was available. A high degree of support was envisaged for only six of these patients: three were felt to require CPN visits and three practical help within the home from an Early Discharge Team. In some cases discharge was being impeded by delays in providing community services: for example one man was awaiting the arrangement of community physiotherapy. A number of instances of
TABLE III

Needs for residential care

\begin{tabular}{lrr}
\hline & $n$ & $(\%)$ \\
\hline Independent accommodation & 6 & $(8)$ \\
Living with family & 7 & $(10)$ \\
\hline & 5 & $(7)$ \\
Transitional hostel & 4 & $(6)$ \\
Rehabilitation unit & 4 & $(6)$ \\
Low-staffed hostel & 14 & $(20)$ \\
High-staffed hostel & 2 & $(3)$ \\
Nursing home & 21 & $(30)$ \\
\hline Hostel ward & 5 & $(7)$ \\
Acute ward & 1 & $(1)$ \\
Intensive care & & \\
Medical ward & & \\
\hline
\end{tabular}

inappropriate admission were identified: for example an alcoholic woman was admitted following detoxification on a medical ward. Staff were unclear about the aims of her in-patient stay. In general, however, it was clear that the threshold for admission to the unit was much higher than the threshold for discharge.

Twenty-nine patients $(41 \%)$ were felt to need one of a number of staffed non-hospital residential placements, the majority into long-term hostels with day-time only staffing (four cases) or 24 hour staffing ( 14 cases). The latter figure included four patients suitable for Part III accommodation. A residential setting focusing on active rehabilitation was felt to be appropriate for four patients. Five patients were rated as requiring a stay in a transitional hostel prior to discharge to their own homes: they needed some support but were not so ill as to require 24 hour nursing care.

No patient was felt to require sheltered housing or a traditional group home. Neither was any current need for residential care in a crisis hostel as opposed to a hospital setting encountered in the survey, although it was noted that one patient might have made use of such a facility at the time of admission had it been available.

The special needs of younger patients suffering from dementing illnesses were particularly apparent and deserve separate mention. Five such patients under the age of 65 were identified on the 'acute' wards: some clinical details are shown in Table IV. All were inappropriately placed and required long-term residential care. The Table also shows the results of follow-up 15 months later. The heterogeneous nature of the clinical problems presented by this group of patients makes them particularly difficult to plan for.

The proposed alternative residential care should not be seen in isolation. A substantial need for day care and 'personal support services' was identified (Tables V and VI). 
TABLE IV

Characteristics of patients suffering from presenile dementias

\begin{tabular}{|c|c|c|c|c|c|}
\hline $\begin{array}{c}\text { Age } \\
\text { (years) }\end{array}$ & Sex & $\begin{array}{l}\text { Length of } \\
\text { stay }\end{array}$ & Diagnosis & $\begin{array}{c}\text { Recommended } \\
\text { placement }\end{array}$ & $\begin{array}{l}\text { Follow up } \\
\text { at } 15 \text { months }\end{array}$ \\
\hline 35 & Male & 7 months & $\begin{array}{l}\text { Huntington's } \\
\text { chorea }\end{array}$ & $\begin{array}{l}\text { Highly staffed } \\
\text { hostel }\end{array}$ & $\begin{array}{l}\text { Placed in } \\
\text { Sue Ryder Home }\end{array}$ \\
\hline 46 & Male & 13 months & $\begin{array}{l}\text { Traumatic } \\
\text { brain damage }\end{array}$ & $\begin{array}{l}\text { Highly staffed } \\
\text { hostel }\end{array}$ & $\begin{array}{l}\text { Remains in-patient } \\
\text { on acute ward }\end{array}$ \\
\hline 48 & Male & 2 months & $\begin{array}{l}\text { Alcoholic } \\
\text { dementia }\end{array}$ & $\begin{array}{l}\text { Low staffed } \\
\text { hostel }\end{array}$ & $\begin{array}{l}\text { Placement in } \\
\text { private sector }\end{array}$ \\
\hline 53 & Male & 9 months & $\begin{array}{l}\text { Multi-infarct } \\
\text { dementia }\end{array}$ & $\begin{array}{l}\text { Intensive care } \\
\text { (long-stay) }\end{array}$ & $\begin{array}{l}\text { Died on psycho- } \\
\text { geriatric ward }\end{array}$ \\
\hline 63 & Female & 17 months & $\begin{array}{l}\text { Pre-senile } \\
\text { dementia }\end{array}$ & Nursing home & $\begin{array}{l}\text { In-patient on } \\
\text { psychogeriatric } \\
\text { ward }\end{array}$ \\
\hline
\end{tabular}

TABLE V

Needs for day care

\begin{tabular}{lrr}
\hline & $n$ & $(\%)$ \\
\hline None & 14 & $(20)$ \\
Generic & 5 & $(7)$ \\
Social club & 4 & $(6)$ \\
Sheltered work & 5 & $(7)$ \\
Highly sheltered work & 2 & $(3)$ \\
Long-term occupational therapy & 12 & $(17)$ \\
Acute day hospital care & 5 & $(7)$ \\
In residential setting & 23 & $(32)$ \\
Unsure & 1 & $(1)$ \\
& & \\
\hline
\end{tabular}

\section{Comments}

These results are, of course, highly speculative and are presented to promote debate rather than as a sound basis for service planning. Judgements about patients' needs for residential care were reliable (inter-informant exact agreement about need for residential care $21 / 24(84 \%)$, interrater exact agreement $7 / 10(70 \%)$ ) but the team approached its task with a common bias in favour of the feasibility of community-based care. The survey took no account of catchment area patients resident in the Maudsley Hospital, some of whom will have been receiving specialist services. (A contemporary census of the Joint Hospitals identified nine patients in specialist units including three in the forensic service, two in a mother and baby unit and two in the drug dependency unit). Neither did the survey take account
TABLE VI

Needs for 'personal support services'

\begin{tabular}{lrr}
\hline & $n$ & $(\%)$ \\
\hline Leaving hospital & 42 & $(100)$ \\
Out-patients & 28 & $(67)$ \\
Depot clinic & 11 & $(26)$ \\
CPN & 18 & $(43)$ \\
Domiciliary visiting & 10 & $(24)$ \\
Home treatment team & 3 & $(7)$ \\
Early discharge team & 10 & $(24)$ \\
Social work support & 18 & $(43)$ \\
\hline
\end{tabular}

of the needs of patients who were not admitted because of an endemic shortage of beds, which had a particular effect on admissions of the elderly, or of the significant numbers of patients being jointly managed on general medical wards.

However, the results do support the contention that a substantial cut in acute bed numbers would be feasible provided that a wide range of alternative facilities was available and accessible. In particular there would have to be a considerable expansion in staffed residential provision, of which there is a great shortage in the area. (Until mid 1986 the local authority provided no staffed accommodation for the mentally ill and at the time of the survey a ban on admissions to Part III homes was in operation due to industrial action. Admission rights for Camberwell residents to long-stay beds within the mental hospital had been lost in 
1978). For such provision to achieve savings in the use of hospital beds, psychiatric teams would require ready access to the non-hospital units. In practice this would mean these facilities becoming operationally part of the psychiatric service. More day care, including a day hospital capable of managing acutely disturbed patients and some expansion in community psychiatric nursing manpower, would also be required.

Interestingly, our survey did not provide evidence that a crisis hostel, recently promoted as a valuable alternative to psychiatric admission, would produce a significant saving in bed usage. A study of the reasons surrounding a series of consecutive admissions is required to provide estimates of the potential demand for such a unit and the other alternatives to admission that might be developed.

We do not believe that it would be either desirable or feasible to run a psychiatric service with the levels of in-patient bed provision advocated in some planning documents. ${ }^{6}$ Attempts to make drastic cuts in bed numbers without the phased introduction of community-based alternatives would lead to an unacceptably low standard of care for patients who would be rapidly cycled through an untherapeutic in-patient facility. There are undoubted positive indications for hospital admission, extending beyond the management of dangerousness, severe psychosis and psychiatric illnesses complicated by significant medical problems. ${ }^{7}$ These include the assessment and reassessment of diagnosis and level of functioning, refinements in drug management and the implementation of treatment programmes that are difficult to provide outside hospital and, most importantly, respite care when the burden of caring becomes too great for families and community support systems. ${ }^{8}$ The need for in-patient care will be greater in areas such as Camberwell where social deprivation makes the support that can be offered by the natural community that much more tenuous, and the conditions to which patients must return after an episode of illness that much worse than the norm.

\section{REFERENCES}

${ }^{1}$ WING, J. K. (ed) (1982) Long-term community care: experience in a London borough. Psychological Medicine Monograph Supplement No 2.

${ }^{2}$ Camber well Health Authority (1986) Local People in Mind. A discussion document.

${ }^{3}$ DHSS (1985) Mental Illness: Policies for Prevention, Treatment, Rehabilitation and Care. London: Department of Health \& Social Security.

${ }^{4}$ Greer, S. \& LidDeLL, D. W. (1972) The department of psychological medicine at King's College Hospital. In Evaluating a Community Psychiatric Service. (eds. J. K. Wing \& A. M. Hailey) Oxford: Oxford University Press.

${ }^{5}$ Hoult, J. (1986) Community care of the acutely mentally ill. British Journal of Psychiatry, 149, 137-144.

${ }^{6}$ South East Thames Regional Health Authorty (1985) Regional Mental Health Strategy 1985-1994. Bexhill-on-Sea: SETRHA.

${ }^{7}$ Stein, L. I. \& TEST, M. A. (1980) Alternative to mental hospital treatment. I. Conceptual model, treatment program and clinical evaluation. Archives of General Psychiatry, 37, 392-397.

${ }^{8}$ TALBOT, J. A. \& Glick, I. D. (1986) The in-patient care of the chronically mentally ill. Schizophrenia Bulletin, 12, 129-140.

\section{New Publications}

Neuropsychiatry, Neuropsychology, and Behavioral Neurology, A Journal of Clinical Neuroscience, is being published quarterly. Suitable articles for editorial consideration are welcomed and should be sent to Michael Alan Taylor, MD, Department of Psychiatry and Behavioural Sciences, University of Health Sciences, The Chicago Medical School, 3333 Green Bay Road, North Chicago, IL 60064, USA. Subscription details are available from: Subscription Department, Raven Press, 1185 Avenue of the Americas, New York, NY 10036, USA.

Good Practices in Mental Health in Richmond, Surrey is a 71 page report giving summaries of 27 projects that illustrate examples of good ideas and practices in mental health services in the district, together with a list of other support services. It is available from Mrs Caroline Walker, 45 Nassau Road, London SW13, price $£ 1.50$ per copy, plus $50 \mathrm{p}$ postage and packing; cheques should be made payable to RABMIND.
14 Prince's Gate: Home of the Royal College of Practitioners traces the story of the College building from the early development of the site in the 18 th century through to the present day and is published by the College to commemorate the 25th anniversary of its ownership of 14 Prince's Gate. It is available from the Central Sales Office, Royal College of General Practitioners, 14 Prince's Gate, Hyde Park, London SW7 1PU, price $£ 8.50$ including postage. Cheques should be made payable to RCGP Enterprises Ltd. There is also a special offer whereby this publication and $A$ History of the Royal College of General Practitioners ( $£ 10.00)$ can be bought together for $£ 16.00$.

Minor Tranquillisers: Hard Facts, Hard Choices is now available in eight languages: Bengali, Cantonese, English, Greek, Hindi, Punjabi, Turkish and Urdu. It is available from MIND's Mail Order Service, 24-32 Stephenson Way, London NW1; price, including postage and packing, 25p each, $£ 2$ for $10, £ 18$ for 100 . Cheques should be made payable to MIND. 